\title{
VAT IN DIGITAL ELECTRONIC COMMERCE
}

\author{
Maruša Pozvek *
}

\begin{abstract}
The dynamics of economic and technological development incur permanent changes in taxation on VAT. Cross-border e-commerce has the potential to reshape and step up the European internal market for consumers through encouraging businesses to sell to consumers abroad and increasing consumer confidence in cross-border purchases. While e-commerce has the potential to increase EU welfare substantially, it also faces a number of regulatory barriers in VAT system that block the realisation of this potential. We are at a critical turning point, when it is necessary to set the right foundations in the VAT system so that digital market can work without problems. Current legislation on VAT introduces uncertainty and ambiguity, which will most likely lead to disputes.
\end{abstract}

\section{INTRODUCTION}

E-commerce is seamless application of information and communication tehnology from its point of origin to its endpoint along the entire value chain of business processes conducted electrinically and designed to enable the accomplishment of business goal. These processes may be partial or complete and may encompass business to business as well as business to consumer and consumer to business transactions. ${ }^{1} \mathrm{E}$ - commerce is generic term that is used to describe technology, processing and operations that occur when business or financial transactions are conduct by electonic means. ${ }^{2}$ VAT is a constant issue

\footnotetext{
PhD Candidate at Faculty of Law, University of Maribor; marusa.pozvek@gmail.com

1 Basu S., Global Perspectives on E-Commerce Taxation Law, Ashgate Publishing, Ltd., 2007 p. 15

2 B.A. Van der Merwe VAT and e - Commerce, SA Mercantile Law Journal = SA Tydskrif vir Handelsreg, Volume 15, Issue 3, Jan 2003, p. 371 - 387
} 
to be considered for all internet-based businesses, e-commerce transactions and shareholders of IT companies. E-commerce markets offer significant rewards not only for entrepreneurs, but also for tax authorities. The dynamics of economic and technological development incur permanent changes in taxation on VAT. Taxation of digital business and e-commerce is currently in the focus of international organisations. ${ }^{3}$

Beside the classification problems between the traditional form of goods and services themselves, due to the highly developing computer and communication technologies, which enable many goods to be easily transformed into dematerialized products, a proper distinction between these traditional forms of supplies and electronically supplied services becomes necessary as well. The famous textbook case considers the distinction of newpapers and magazines being supplied through different forms of distribution channels. From the VAT point of view,printed versions are considered to be goods while the online version, with the same or similar content, is deemed to be a service. This characterization applies to many other products such as music, software, and films. Until a few years ago buying those products in a physical format was common practice, whereas downloads are now the dominant form which might also have an influence on their characterization for VAT. The software stored on a physical support is generally considered to be a good while its electronic download is considered to be a service. This change in characterization involves a change in the rule applicable for determining the place of taxation, VAT rates and other administrative obligations. In cross-border trade, the place of supply for the dematerialized product will not be determined by the place where the transport begins (with possible application of zero rate for export) but the place where the provider and customer are located. Such a classification may have an impact beyond the place of taxation issue. For example, many countries apply reduced rates (or even zero rates) to newspapers in their paper form while they apply the standard rate to the electronically delivered substitute. Referring to Directive 2009/47/EC which includes an extension of the possibility to apply reduced rates for printed books also to books on all physical means of support, the Member States' interests in the politically sensitive area of reduced rates have led to strong opposition against any further extension of the possibility to apply reduced rates, although the new socioeconomic realities and technological developments are acknowledged. ${ }^{4}$

\footnotetext{
Bellheim A., Brown C., Erneholm F., Jundt M., Your pocket guide to VAT on digital e-commerce et. al., Bird \& Bird Advokat KB Printed in Stockholm, Sweden, in July 2014. p. 5 4 Goeydeniz S. IFA Research Paper: VAT on Cross-border Services IFA Research Associate , IBFD 2010, p. 6
} 


\section{ELECTRONICALLY SUPPLIED SERVICES}

Taxable transactions include the supply of goods and the supply of services. ${ }^{5}$ Article 11 of EU Regulation 1777/2005 provides a comprehensive definition of electronically supplied services, which needs to be distinguished from traditional services. An "electronically supplied service" is one that:

- in the first instance is delivered over the Internet or an electronic network ${ }^{6}$, and then

- the nature of the service in question is heavily dependent on information technology for its supply?

Therefore, on the basis of this two step test, an "electronically supplied service" includes inter alia:

- digitised products generally, such as software and changes to or upgrades of software; or

- a service which provides, or supports a businessor personal presence on an electronic network (e.g. web site or web page); or

- a service automatically generated from a computer, via the Internet or an electronic network, in response to specific data input by the customer.In general, the use of the Internet or other electronic networks by parties to communicate with respect to transactions or to facilitate trading does not affect the normal VAT rules that apply to traditional services.

For example, where parties simply use the Internet to convey information in the course of a business transaction, this does not change the nature of that transaction. This is illustrated by the case of a lawyer writing an opinion for a customer where the entire communication and the report is delivered via e-mail. That transaction would be covered by the traditional supply of services. This differs from a supply that is completely dependent on the Internet in order to be carried out (e.g. searching and retrieving information from a database with no human intervention), following the rules for electronically supplied services. Categorization of services according to their nature may, however, create difficulties. In some cases it can involve different tax treatment for similar products. The separation of electronically supplied services from other services that involve the use of the Internet and of computer equipment

\footnotetext{
5 Basu S., Global Perspectives on E-Commerce Taxation Law, Ashgate Publishing, Ltd.,2007 p.70

6 i.e. reliant on the Internet or similar network for its provision

7 i.e. the service is essentially automated, involving minimal human intervention and in the absence of information technology does not haveviability.
} 
but that are not purely automated can raise difficulties. For example, in the case of a supply of distance learning, it could be considered cumbersome to apply different regimes to long-distance live classes (with the remote presence of a human teacher) and purely virtual classrooms with no human intervention at all.That a television or radio programme is regarded as an electronically supplied service only if it is broadcasted over the Internet again illustrates the difficulties concerned. It doesn't become easier with real composite or bundled supplies, which do consist of several transactions which are treated differently from a VAT point of view (one taxable, the other tax-exempt) where the components are normally not sold separately, but the customer acquires one good or one service for one price. If the consideration is related to a principal supply, the amount may not be apportioned. If, on the other hand, the supply consists of distinguishable elements, the consideration may be apportioned. In other words, the type of goods or services or the combination thereof must be clarified in order to determine, if a principal supply is apparent or if the amount must be apportioned. Due to conceptional issues the EU considers products ordered and delivered by the Internet or other networks as supply of services. However, it may be argued that paper and electronic media are different products since they do not offer the same services/functions to the customer. For example, the electronic version usually offers search and other functions that are not possible to be enjoyed with the tangible product as such, which could justify the different treatment due to the supply classification. ${ }^{8}$ However, if a subscription to newsletters against an annual fee is present, the annual fee may be regarded as the consideration. A membership agreement is also conceivable, where the membership fee could fulfil the objectives laid down by the ECJ. In applying these criteria to digital supplies, does it mean that all downloads made free-of-charge cannot be covered by VAT since there is no consideration as such? Whether exchanging files via the internet could also be characterized as consideration in peer-to-peer situations depends whether there is a direct link between the supply and the payment, which could occur by exchanged files. In peer-to-peer situations one must consider how files are transferred between the users. In the case of platform providers where bits and pieces of files are downloaded from different users, it may thus be difficult establishing a direct link between the exchanged files. Agreeing to the terms of use and downloading the required software could be the direct link that also creates a legal relationship. The subjective value from how many files have been uploaded from each user and a nominal value for these files could be tracked and calculated. ${ }^{9}$

\footnotetext{
8 Goeydeniz S. IFA Research Paper: VAT on Cross-border Services IFA Research Associate, IBFD 2010 p. 7

9 Goeydeniz S. IFA Research Paper: VAT on Cross-border Services IFA Research Associate, IBFD 2010 p. 8
} 
Cross-border e-commerce has the potential to reshape and step up the European internal market for consumers through encouraging businesses to sell to consumers abroad and increasing consumer confidence in cross-border purchases. ${ }^{10}$

While e-commerce has the potential to increase EU welfare substantially, it also faces a number of regulatory barriers that block the realisation of this potential. Far from perfect VAT system accounts for a significant part of the obstacles. The fundamental driver of problems is the differences in VAT rates within the EU. The differences exist in three dimensions. First, there are substantial differences between Member States in the VAT rates that they apply to the same types of typical e-commerce products. This provides, in some circumstances, an incentive for private consumers to source products from the country with the lowest VAT rate. Second, physical variants of products are in a number of cases taxed at lower rates than the digital variants within countries: a classic example is physical versus electronic books. This provides a VAT-induced incentive to choose the physical variants. It also creates the so called mixed supply problem: if two products with different VAT rates are sold by the same supplier to a customer: what VAT rate should apply? For instance, a consumer may acquire the right to both a hardcopy newsletter/ magazine and access to an online soft copy version for a single price. Third, the VAT treatment that can apply to certain suppliers can provide the supplier with an advantage in the distribution or facilitation of the e-commerce trade: universal post service providers and certain payment facilitators may be able to apply VAT exemptions to their services, respectively, transporting physical goods and providing payment facilities. ${ }^{11}$

A person in Jurisdiction A may contact a company for the development of software in Jurisdiction B, download the newly developed software to a laptop computer in Jurisdiction $\mathrm{C}$ and use it, for example, at a business conference in Jurisdiction D. In these circumstances, a case could be made for determining that consumption takes place in whatever jurisdiction the software is accessed and used. However, this would be impossible to administer. In most cases it would be difficult for a business to track usage of services in this way and difficult for a tax administration to know, where the service was used. Even if the usage could be tracked, it would again, be difficult to place a monetary value on it, in order to determine an amount of tax due and the compliance burdens on business and tax administrations would be unreasonabe. ${ }^{12}$

10 Schoorl P. - Crni Conference, 19 November Brussels DRAFT VAT Modernization and Competition in the Cross-Border Mail Market p.22

11 Simplifying and Modernising VAT in the Digital Single Market for e-Commerce, The Directorate-General for Internal Policies, Brussels, september 2012 p.10

12 Goeydeniz S. IFA Research Paper: VAT on Cross-border Services IFA Research Associate, IBFD 2010 p. 16 


\subsection{THE IMPACT OF VAT ON DIGITAL ELECTRONIC COMMERECE IN THE EUROPEAN UNION}

The establishment of an internal market where goods and services are exchanged without tax and administrative obstacles between the member states is a fundamental objective of the European Community. To ensure the concept of an area without internal frontiers, the European Community Treaty contains harmonization provisions. To this end Article 93 of the European Community Treaty authorises the European Council to adopt VAT Directives. The EU members are required to implement the Directive's requirements into domestic law. Since 1967 several VAT Directives have been released and for the supply of goods and services the Sixth Directive (1977) is of particular importance. ${ }^{13}$ VAT Directive may be compared to a multinacional VAT treaty agreement between EU Member states. ${ }^{14}$ E-commerce creates VAT compilance and reporting obligations for business that can be chalenging and burdensome. In addition to the requirement to maintain VAT registrations, file preiodical VAT and other statistical returns, there are a number of other considerations that are particular to the industry. ${ }^{15}$ VAT neutrality in international trade is generally achieved by the use of the destination principe. ${ }^{16}$ In Europe, the EU Commission has been pursuing the application of the destination principle in relation to sales of digital e-commerce products to final consumers in the EU so that they are subject to VAT in the consumer's country. This brings the VAT treatment of these services in line with one of the main principles of VAT that, as a consumption tax, tax revenues should accrue to the Member State in which goods/ services are actually consumed. The EU Commission feels that the application of the destination principle provides a basis for a sustainable solution to the challenges raised by the digital economy, on the basis that it should ensure a level playing field for operators providing goods and services from a remote location. In this respect, the meaning of the term"digital e-commerce"as the subject matter of this guide needs further clarification - this is because a distinction needs to be made for VAT purposes between the following types of supply:

\footnotetext{
13 Alexiou C., Morrison D., The cross-border electronic supply eu-vat rules: lessons for Australian gst, available at http://www.austlii.edu.au/au/journals/RevenueLawJ1/2004/7.pdf last accessed on 12/6/2017

14 Bardopoulos A. M. eCommerce and the Effects of Technology on Taxation: Could VAT be the eTax Solution?, Springer 2015 p.35

15 Radia N., Considerations for e- commerce, International tax review, september 2013

16 Pfeiffer S., Ursprung-Steindl M., Global Trends in VAT/GST and Direct Taxation: Schriftenreihe IStR Band Linde June 2015 p.21
} 
1. a supply of digital products delivered over the internet without needing a distinct physical presence in the markets in which the service provider operates - this also covers digital products kept at a central data centre and distributed as a service (e.g. cloud services);

2. supplies of other services over the internet (e.g. consultancy, teaching); and

3. supplies of tangible products e.g. goods, ordered and sold online.

A digital e-commerce business model would include, for example, downloading an e-book in return for a fee or online streaming services in return for a fee. Such digital products are delivered via the internet or an electronic network and their supply is essentially automated and involves no or minimal human intervention. They can be distributed and supported by suppliers from locations that are very distant from the locations where the product is actually consumed by a consumer, and/or consumers can access the products from any location they choose provided there is internet access. Mailing a printed book, receiving professional services such as consultancy via email, purchasing theatre tickets or access to similar events as well as accommodation, car-hire, restaurant services, passenger transport and similar services via the internet are examples. In such cases, the internet or similar electronic network is being used as a tool for communication and distribution between the supplier and consumer, but it should not alter the nature of the underlying supply being provided - i.e. a purchase of goods or admission to an event. Accordingly, the principles of the EU's VAT Directive particular to such supplies should apply to determine their VAT treatment. In such cases, the place of taxation may depend on whether the supply is to another business (a"B2B" transaction) or to a final/private consumer (a"B2C" transaction), or, where the event is actually performed, irrespective of the identity/status of the customer (for example, theatre tickets). ${ }^{17}$ Cross-border e-commerce has the potential to transform and strengthen the European internal market for consumers by encouraging companies to sell to consumers abroad and increasing consumer confidence for cross-border purchases. However, according to recent figures, the Commission notes that e-commerce is still very fragmented along national lines; 150 million people in the EU are regularly shopping online, but only 30 million Europeans ( 7 percent of the population), cross-border purchases. ${ }^{18}$ For e commerce consumers typically use a global platforms.We need to highlight that eBay Inc.'s Marketplaces and PayPal businesses are true global platforms, but the

17 Bellheim A., Brown C., Erneholm F., Jundt M., Your pocket guide to VAT on digital e-commerce et. al., Bird \& Bird Advokat KB Printed in Stockholm, Sweden, in July 2014, p 8-11

18 Schoorl P. - Crni Conference, 19 November Brussels DRAFT VAT Modernization and Competition in the Cross-Border Mail Market p. 22 
majority of users and volume comes from outside the U.S. In 2013, eBay Inc. enabled \$212 billion of commerce worldwide. eBay is one of the world's largest online marketplaces, with $128 \mathrm{~m}$ active users and $500 \mathrm{~m}$ listings worldwide their cross-border business is strong and growing fast.eBay's global buying hub focuses on localising sites for larger markets outside the U.S.. The picture below shows a strong commercial corridors that already exist: ${ }^{19}$ :

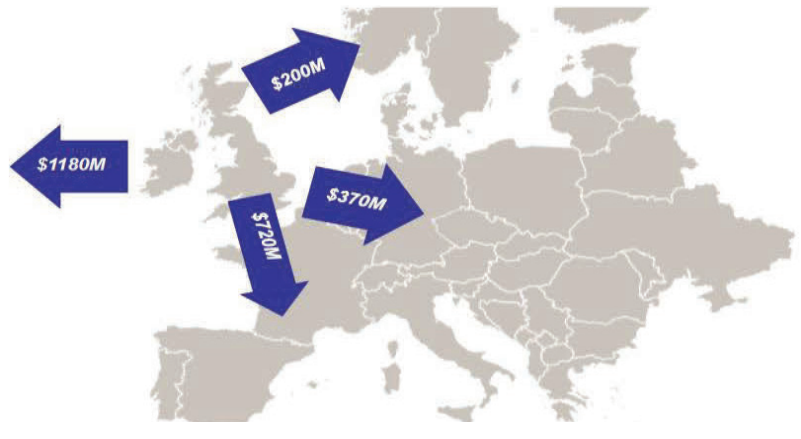

\subsubsection{B2B DIGITAL TRANSACTIONS IN E-COMMERCE}

Normally, if digital e-commerce services are rendered by non-EU/EU suppliers to an entrepreneur resident in another Member State on a cross-border basis, they are subject to VAT at the place where the recipient entrepreneur is established. Very broadly, this is either the country where it is registered and has its head office or, where more appropriate, the country where it has fixed premises and staff receiving the service. To verify the status of the recipient and where they belong, suppliers can rely on a valid VAT identification number communicated by the recipient in respect of the supply. The recipient of such supply would then usually be required to account for VAT on the supply under the reverse charge mechanism which transfers the liability of VAT from the supplier to the recipient. Consequently, the supplier should issue an invoice without VAT. According to the reverse charge mechanism the recipient of the digital e-commerce service has to declare the VAT due to the tax authorities via their VAT return as if they were the supplier. However, the recipient can usually make a corresponding input VAT deduction at the same time and in the same amount as the VAT due (provided that he does not carry out certain VAT-exempt supplies - such as financial services - in which case the recipient cannot deduct the VAT) such that the transaction is normally cash flow-neutral

19 Drake P. Breaking barriers toward greater Cross-border e-commerce and a new retail economyHolland, European Expansion and Cross-Border Trade, Ebay Marketplaces Europe annual conference 2014, p. 42 
for the recipient. As noted, VAT is an end consumer tax and each business in a supply chain can to the extent it makes VAT able supplies deduct the input VAT it is charged on business costs of goods and services. Those costs are built into the price of the end product as sold to final consumers, and therefore VAT should, assuming the final consumer is in the same Member State as the last business in the supply chain, accrue to the Member State of consumption pursuant to this reverse charge mechanism. ${ }^{20}$

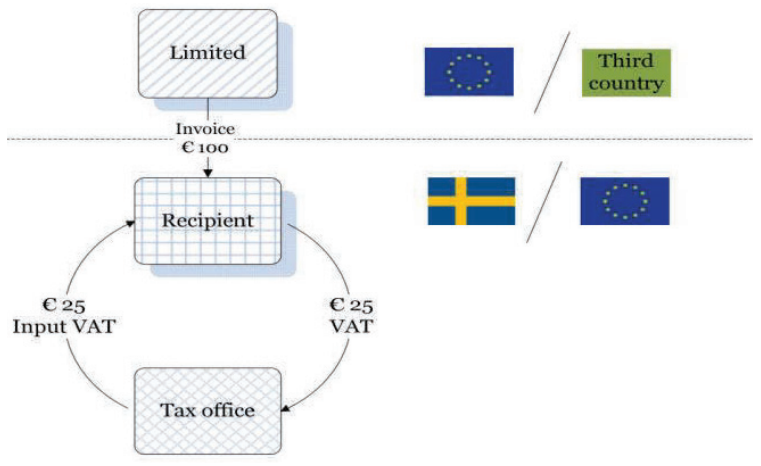

\subsubsection{B2C DIGITAL TRANSACTIONS IN E-COMMERCE AND LOCATION OF THE CONSUMER}

The only type of e-commerce that is problematic involves sales of digital content to consumers and unregistered traders. However, such sales constitute a minuscule fraction of purchases by households and unregistered traders (given the extremely low level of small-business exemptions). ${ }^{21}$

Accordingly, the Commission and Member States have taken measures so EU VAT legislation will no longer distinguish between EU suppliers and non-EU suppliers making electronically-supplied services and also telecommunications and broadcasting services to final consumers. As a result, VAT will be due on the supply in the Member State where the final consumer belongs irrespective of where the supplier is established, at the VAT rate applicable in that Member State.

\footnotetext{
20 Bellheim A., Brown C., Erneholm F., Jundt M., Your pocket guide to VAT on digital e-commerce et. al., Bird \& Bird Advokat KB Printed in Stockholm, Sweden, in July 2014, p.12 21 Charles E. McLureJr. The Value Added Tax on Electronic Commerce in the European Union, International Tax and Public Finance, November 2003, Volume 10, Issue 6, pp 753-762
} 

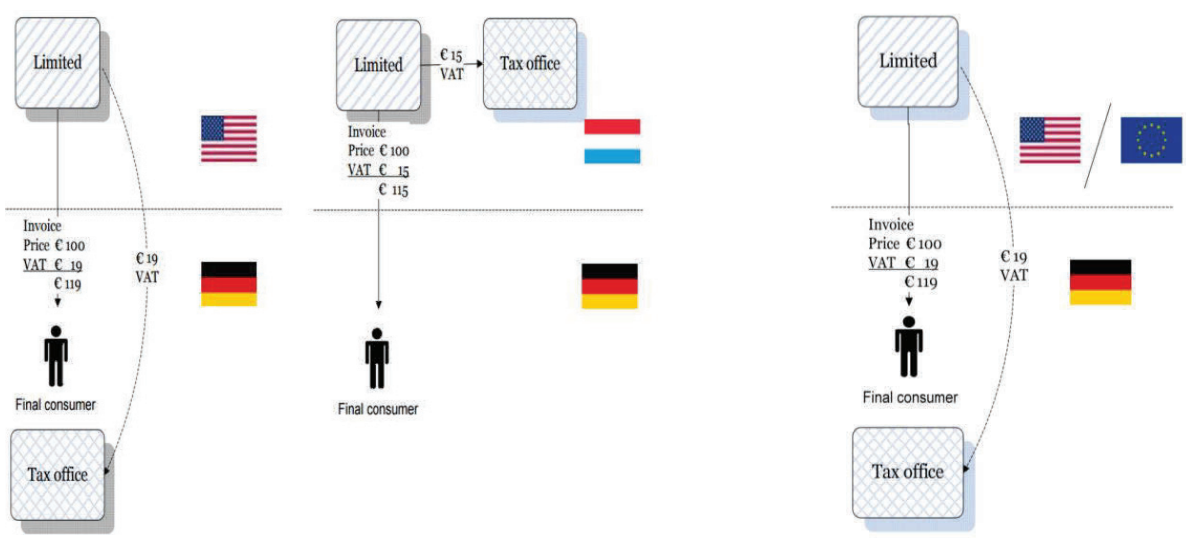

The first issue for suppliers to consider is whether their supply falls within the definition of a digital service, particularly if they are sold as part of a package with other goods or services not covered by these changes. It is necessary in those cases to determine whether the bundle is a single supply and if so, how to characterise the nature of the supply. A supply can consist of one or more elements. If there are more elements, a transaction comprising a single supply from an economic point of view should not be artificially split. The essential features of the supply must be ascertained in order to determine whether the consumer receives several distinct principal supplies or a single supply, and whether the digital service is the principal supply, part of a mixed supply or ancillary or additional to a non-digital principal supply. For example, if the supplier provides both printed material and digital access to the content, the supplier would need to determine if the digital element is caught by the new rules. This will very much depend on facts taking into consideration relevant case law of the European Court of Justice. Evidence of consumer location the key challenge for suppliers of B2C digital services will be in determining where the final consumer belongs, and therefore where VAT will be due. As noted by the Commission Expert Group, in the traditional economy, this is not usually an issue as the place of consumption of a meal is the restaurant, the delivery address for a good etc. Complications however arise in respect of digital supplies as it can be difficult to identify the place of consumption especially with the growth of mobile devices such as tablets and smart phones and the ability of customers using such devices to buy digital services in a Member State in which they are not established. ${ }^{22}$

22 Bellheim A., Brown C., Erneholm F., Jundt M., Your pocket guide to VAT on digital e-commerce et. al., Bird \& Bird Advokat KB Printed in Stockholm, Sweden, in July 2014, p. $16-22$ 


\section{THE SUPPLY OF APPS}

The EU VAT treatment of the supply of apps can be very complex due to the whole range of supply possibilities and supply chain scenarios, e.g. through a telecommunications network, via an interface, a portal or an online app store, whereby apps can be supplied to a final consumer indirectly by the developer via an intermediary or several intermediaries taking part in the supply. In general, a typical app store business model could be as follows:

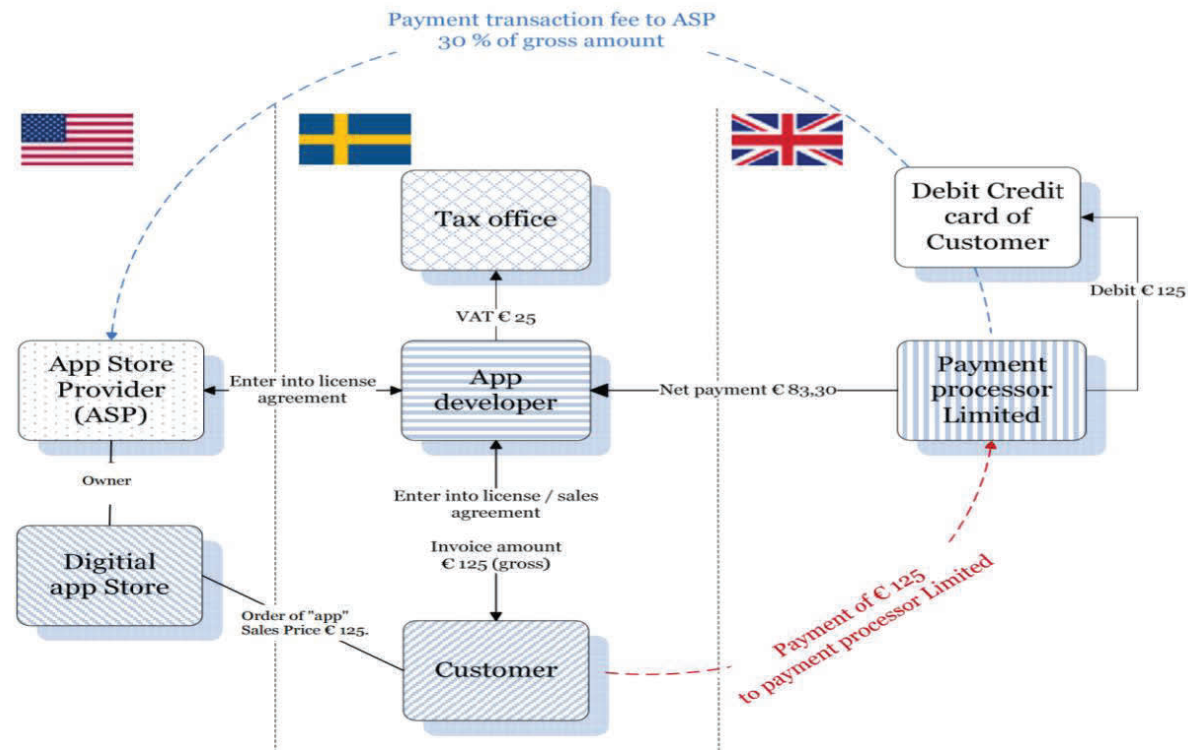

As indicated in the diagram above, the contractual relationships could be as follows: The final consumer purchases the app via the app store and enters into a contract with the app developer and/or app store; the app developer concludes a contract with the app store provider, and enters into a separate contract with a payment processor (e.g. mobile operator/credit card company) which debits the final consumer the gross price for the app. It withholds a certain percentage of the gross amount and forwards this percentage to the app store provider and/ or to the bank/telecomprovider (if the final consumer pays through its mobile provider). The remaining amount is then forwarded to the app developer. The supply chain is often long and can stretch across borders. In such cases, it can be challenging to determine the point in time when the services are actually supplied to a final consumer and the identity of the actual supplier in the supply chain who should be responsible for the VAT payment on that supply. In general, the EU VAT treatment should follow the contractual agreements between the parties involved so long as they reflect the economic reality of 
the arrangements.The Commission's detailed guidance lists certain indicators which would suggest an intermediary takes part in a supply, including as follows: being responsible for the actual delivery; owning or managing the technical platform over which the services are delivered; controlling or exerting influence over the pricing of the service; providing customer care or support in relation to queries about or problems with the e-service itself; owning the customer data related to the supply; and being in a position to credit a sale without the supplier's permission or prior approval in cases where the supply was not properly received. ${ }^{23}$

\section{THE USE AND ENJOYMENT RULE}

European Union has been aggressive in the taxation of the of e-commerce transactions. Initially E.U. mamber nations collected VAT on e-commerce purchases based on the seller's location. The seller based taxed however disatvantaged EU firms in intrenational market. ${ }^{24}$ The place of consuption for cross border supplies of services and intangible property that are capable of delivery from a remote location made to a non resident private recipient should be in the jurisdiction in which the recipient has their usual residence. ${ }^{25}$ To prevent double taxation, non-taxation or distortion of competition, Member States may decide to shift the place of supply of digital e-commerce (and certain other) services as determined under the normal rules, using a special override rule based on the "effective use and enjoyment" of the service. This additional provision seeks to correct instances of distortion which could remain as a result of considering, for example, only where the service provider and/or the customer

\footnotetext{
23 Conversely, indicators of an intermediary not taking part in a supply could include internet providers/mobile operators/payment service providers who are only processing payment and/or making a network available for the carrying of content, the argument being that such participation should not be sufficiently relevant and merely facilitates the flow of cash and/ or content. However, mobile operators can be seen as taking part in a supply if the network is essential for the supply or if their payment collection does not only cover a simple charge but includes other elements (e.g. use of premium SMS). Suppliers should assess the effect of this new rule on their $\mathrm{B} 2 \mathrm{~B}$ contracts with intermediaries and on platforms on which they supply their B2C digital services, and ensure there is a clear, common agreement within the supply chain as to which party is legally responsible for accounting for the VAT due on the ultimate B2C transactions.Bellheim A., Brown C., Erneholm F., Jundt M., Your pocket guide to VAT on digital e-commerce et. al., Bird \& Bird Advokat KB Printed in Stockholm, Sweden, in July 2014, p.42-43

24 Encyclopedia of E-Commerce Development, Implementation, and Management, Band 1IGI Global 2016, p.2306

25 Ecker T., A VAT/GST Model Convention Volume 25 IBFD, Doctoral Series May 2012 p.276
} 
belong. In effect, the rule allows Member States to disregard the "place of supply" position provided for under the normal rules and instead consider that:

- Even though the place of supply of digital services would be situated within their territory (because the customer belongs there), the place of supply may be considered as being situated outside the EU, if the "effective use and enjoyment" of the service takes place outside the EU;

- Even though the place of supply of digital services would be situated outside the EU (because the customer belongs there), the place of supply may be considered as being situated within the EU country, if the "effective use and enjoyment" of the service takes place within their territory.

Broadly this means that, for EU VAT purposes, Member States can only apply the "effective use and enjoyment" rule to tax services actually consumed within their territory if those services have been supplied to customers that belong in a third/non-EU country (rather than to a customer belonging in another Member State). ${ }^{26}$

\section{CASE C 390/15}

In the light of the constant developments to which electronic services in their entirety are subject,it was considered necessary to make electronic services subject to clear, simple and uniform rules in order that the VAT rate applicable to them may be established with certainty and, thus, that the administration of VAT by taxable persons and national tax authorities is facilitated. By precluding the application of a reduced rate of VAT to electronic services, the EU legislature spares taxable persons and national tax authorities from an obligation to examine, for each type of those services, whether it falls within one of the categories of services that qualify for such a rate under the VAT Directive. Consequently,such a measure must be regarded as being appropriate for achieving the objective pursued by the specific VAT regime for e-commerce. Moreover, to accept that the Member States are able to apply a reduced rate of VAT to the supply of digital books electronically, as is permitted for the supply of such books on all physical means of support, would effectively compromise the overall coherence of the measure intended by the EU legislature, which consistsin the exclusion of all electronic services from the possibility of a reduced rate of VAT being applied. ${ }^{27}$

26 Bellheim A., Brown C., Erneholm F., Jundt M., Your pocket guide to VAT on digital e-commerce et. al., Bird \& Bird Advokat KB Printed in Stockholm, Sweden, in July 2014, p . 27

27 Court of Justice of the European Union PRESS RELEASE No22/17 Luxembourg, 7 March 2017Judgment in Case C-390/15Rzecznik Praw Obywatelskich (RPO) available at https://cu- 
In Case C 390/15 Court (Grand Chamber) hereby ruled that Examination of the questions referred for a preliminary ruling has disclosed no factor of such a kind as to affect the validity of point 6 of Annex III to Council Directive 2006/112/EC. ${ }^{28}$

Advocate General Juliane Kokott takes the view of the question of whether digital and printed publications within the meaning of the case-law in Case C 390/15 are, in general sufficiently comparable. Advocate General's opinion is that it must also be examined whether the differing treatment of all digital publications that are transmitted electronically compared with printed publications resulting from point 6 of Annex III to the VAT Directive, in conjunction with Article 98(2) of that directive, might infringe the principle of equal treatment. Significant difference exists between digital publications that are transmitted by electronic means and printed publications with regard to their need for support, which results from the very different distribution costs. Account would also have to be taken of the EU legislature's discretion in assessing the competitive situation. However, even if their comparability were to be assumed, the difference in treatment of publications transmitted by electronic means and printed publications would currently be justified. This results, as has been seen, in particular from the legitimate legislative objective of providing for a special taxation scheme for electronic services. In this respect, the differing treatment of publications transmitted electronically compared with printed publications is even more appropriate, as the competition situation is likely to be less pronounced than is the case with identical digital publications. Accordingly, the principle of equal treatment is also not infringed in so far as point 6 of Annex III to the VAT Directive, in conjunction with Article 98(2) of that directive, excludes electronically transmitted publications, in contrast to printed publications, from the scope of application of the reduced tax rate.

\section{CONCLUSION}

Although E- commerce is a little over 20 years old it is still in its infancy. ${ }^{29} \mathrm{E}$-commerce is growing and represents a key part of the digital economy. VAT has strong impact on cross-border sales of physical and digital products

ria.europa.eu/jcms/upload/docs/application/pdf/2017-03/cp170022en.pdf , last accessed on 12/5/2017

28 Of 28 November 2006 on the common system of value added tax, as amended by Council Directive 2009/47/EC of 5 May 2009, or of Article 98(2) of that directive, read in conjunction with point 6 of Annex III thereto.

29 Lodder, Arno R., Murray Andrew D., EU Regulation of E-Commerce: A Commentary Edward Elgar Publishing 2017, p.8 
in e-commerce. Modernization of VAT for cross-border e - commerce seeks to provide a simple, effective, neutral VAT system for the single market.

The Commission has consistently pressed for the reform of the VAT system. The initiatives that were then achieved included implementation of the new place of supply rules, in line with the general principles, at the place of destination, for telecommunications, broadcasting and electronic services provided to final consumers with a One Stop Shop to facilitate tax compliance. ${ }^{30}$ The European Commission in its documents mentioned DSM strategy ${ }^{31}$ which aims to reduce the burdens and barriers in relation to VAT on sales via borders, in order to increase the potential growth of the European digital economy. With Digital Single Market Strategy EU Commission will try to reduce the administrative burden on businesses arising from different VAT regimes, single electronic registration and payment and common VAT threshold. ${ }^{32}$ The Commission seeks to ensure the same conditions for EU companies and to ensure that revenues from VAT belong to the Member State of the last link in the chain. VAT is a tax which is used in 150 countries around the world. Taxpayers have become global traders and consumers the global buyers. The VAT system presents obstacles and difficulties in international trade of goods and services, because there is no harmonization. Numerous administrative obstacles are slowing international trade and preventing the flourishing of many economies. The problem is even greater when it comes to digital operations. The biggest issue is that the service may be present in many parts of the world at variety of consumers and only with a single click. Complications occur mainly in the field of determining who bears the final tax burden. The rules in this area are quite vague or non-existent, therefore in practice provisions relating to physical goods apply in digital cases. A few years ago we would not even think that we will be able to communicate with each other through an invisible network as well as purchasing a variety of products and services. Today this is our reality and we can only magine how it will in 10 from now, when the technology will be even more advanced. We are at a critical turning point, when it is necessary to set the right foundations in the VAT system so that digital market

\footnotetext{
30 Communication from the commission to the European Parliament, the Council and the European Economic and social committee on an action plan on VAT towards a single EU VAT area -Time to decide, Brussles 2016, p.5

31 Digital Single Market Strategy adopted by EU commission includes a set of targeted actions to be delivered by the end of next year . It is built on three pillars: (1) better access for consumers and businesses to digital goods and services across Europe; (2) creating the right conditions and a level playing field for digital networks and innovative services to flourish; (3) maximising the growth potential of the digital economy.

32 Digital Single Market Strategy available at https://ec.europa.eu/commission/sites/beta-political/files/2-years-on-dsm_en_0.pdf, last accessed on 17/5/2017.
} 
can work without problems. Current legislation on VAT introduces uncertainty and ambiguity, which will most likely lead to disputes.

\section{LITERATURE:}

1. Alexiou C., Morrison D., The cross-border electronic supply eu-vat rules: lessons for Australian GST, available at http://www.austlii.edu.au/au/journals/RevenueLawJl/2004/7.pdf last accessed on 12/6/2017.

2. Bardopoulos A.M. eCommerce and the Effects of Technology on Taxation: Could VAT be the eTax Solution?, Springer 2015.

3. Basu S., Global Perspectives on E-Commerce Taxation Law, Ashgate Publishing, Ltd., 2007.

4. B.A. Van der Merwe VAT and e - Commerce, SA Mercantile Law Journal = SA Tydskrif vir Handelsreg, Volume 15, Issue 3, Jan 2003, p. 371 - 387.

5. Bellheim A., Brown C., Erneholm F., Jundt M., Your pocket guide to VAT on digital e-commerce et. al., Bird \& Bird Advokat KB Printed in Stockholm, Sweden, in July 2014.

6. Charles E. McLureJr. The Value Added Tax on Electronic Commerce in the European Union, International Tax and Public Finance, November 2003, Volume 10, Issue 6, pp. 753-762.

7. Communication from the commission to the European Parliament, the Council and the European Economic and social committee on an action plan on VAT towards a single EU VAT area -Time to decide, Brussels 2016.

8. Digital Single Market Strategy available at https://ec.europa.eu/commission/sites/ beta-political/files/2-years-on-dsm_en_0.pdf, last accessed on 17/5/2017.

9. Drake P. Breaking barriers toward greater Cross-border e-commerce and a new retail economyHolland, European Expansion and Cross-Border Trade, Ebay Marketplaces Europe annual conference 2014.

10. Ecker T., A VAT/GST Model Convention Volume 25 IBFD, Doctoral Series May 2012.

11. Encyclopedia of E-Commerce Development, Implementation, and Management, Band 1IGI Global 2016.

12. Goeydeniz S. IFA Research Paper: VAT on Cross-border Services IFA Research Associate, IBFD 2010.

13. Lodder, Arno R., Murray Andrew D., EU Regulation of E-Commerce: A Commentary, Edward Elgar Publishing 2017.

14. Pfeiffer S., Ursprung-Steindl M., Global Trends in VAT/GST and Direct Taxation, Schriftenreihe IStR Band Linde June 2015 p.21. 
15. Radia N., Considerations for e- commerce, International tax review, September 2013

16. Schoorl P. - Crni Conference, 19 November Brussels DRAFT VAT Modernization and Competition in the Cross-Border Mail Market.

17. Simplifying and Modernising VAT in the Digital Single Market for e-Commerce, The Directorate-General for Internal Policies, Brussels, September 2012.

18. Court of Justice of the European Union PRESS RELEASE No22/17 Luxembourg, 7 March 2017Judgment in Case C-390/15Rzecznik Praw Obywatelskich (RPO) available at https:/curia.europa.eu/jcms/upload/docs/application/pdf/2017-03/ cp170022en.pdf, last accessed on 12/5/2017.

19. Case C390/15, Rzecznik Praw Obywatelskich (RPO) v Marszałek Sejmu Rzeczypospolitej Polskiej, Prokurator Generalny. ECLI: EU:C:2017:174.

20. Opinion of Advocate General, Kokott delivered on 8 September 2016 in Case C390/15.

21. Council Regulation (EU) No 282/2011 of 15 March 2011 laying down implementing measures for Directive 2006/112/EC on the common system of value added tax (OJ L 77, 23/3/2011).

22. Council Regulation 2009/47/EC of 5 May 2009 amending Directive 2006/112/EC as regards reduced rates of value added tax. (OJ L 116, 9/5/2009).

23. Council Regulation (EU) No 282/2011 as regards the place of supply of services Commission explanatory notes published 3 April 201 4on the EU VAT changes to the place as of 1 January 2015.

24. Council Regulation (EC) No 1777/2005 of 17 October 2005 laying down implementing measures for Directive 77/388/EEC on the common system of value added tax. (OJ L 288, 29/10/2005). 
